\title{
Two-Stage Anaerobic Co-digestion of Landfill Leachate and Starch Wastes Using Anaerobic Biofilm Reactor for Methane Production
}

\author{
DARWIN*, Ulfa Triovanta, RidHo RiNALDI
}

\begin{abstract}
The study aims to evaluate two-stage anaerobic co-digestion of leachate and starch waste using anaerobic biofilm bioreactor to enhance methane production. The anaerobic digestion process was operated under the mesophilic condition at $35 \pm 1{ }^{\circ} \mathrm{C}$. Hydraulic retention time (HRT) applied to the acidogenesis and methanogenesis reactors were 5 and 25 days, respectively. The organic loading rate (OLR) used in the process of acidogenesis was 2.91 gram volatile solid /L.day, while methanogenesis was 0.58 gram volatile solid (VS) per liter per day. Results showed that two-stage process using biofilm was an effective method for operating anaerobic co-digestion of starch waste and landfill leachate in which the system produced higher methane yield at $125.11 \mathrm{~mL}$ methane $\left(\mathrm{CH}_{4}\right)$ per gram volatile solid (VS) added (mL.CH4/g.VS. ${ }_{\text {added }}$ ) in comparison to the single-stage

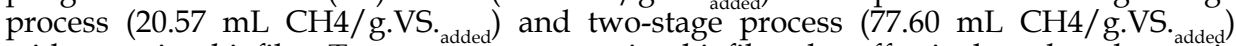
without using biofilm. Two-stage process using biofilm also effectively reduced organic matters in the culture in which the system reached 61\% BOD removal in comparison to the single-stage process and two-stage process without biofilm that only had 27.6 and $39.3 \%$ BOD removal, respectively. This study suggested that the two-stage process using biofilm would be the preferred technique for treating starch waste and landfill leachate.
\end{abstract}

Keywords: two-stage, landfill leachate, starch waste, methane

\section{List of abbreviations}

$\mathrm{BOD}=$ Biochemical Oxygen Demand $\mathrm{COD}=$ Chemical Oxygen Demand $; \mathrm{EC}=$ Electrical Conductivity; $\mathrm{HRT}=$ Hydraulic Retention Time; $\mathrm{g}$ = gram; $\mathrm{L}=$ Liter; $\mathrm{NH}_{4}-\mathrm{N}=$ Ammonium Nitrogen; OLR = Organic Loading Rate; ORP = Oxidation Reduction Potential; TAN = Total Ammoniacal Nitrogen; TDS = Total Dissolved Solids; TKN = Total Kjedahl Nitrogen; TS = Total Solids; VFA = Volatile Fatty Acids; VS = Volatile Solids

*Corresponding author. E-mail address: darwin_ae@unsyiah.ac.id Department of Agricultural Engineering, Syiah Kuala University, Banda Aceh 23111, Indonesia 


\section{Introduction}

Anaerobic digestion is the technology that has been widely recognized and applied in waste treatment process. This is due to the fact that the technology is effectively used for biologically treating the organic liquid and solid wastes prior to the disposal [1]. Currently, anaerobic digestion has become an attractive technology that has been developed for the conversion of organic waste into valuable products such as renewable energy (i.e. biogas) and biofertilizer. Yenigün and Demirel [2] mentioned that recently study on anaerobic digestion has been conducted in various aspects including process performance and stability, operational and environmental parameters, inhibition and toxicity, and optimization of end-product formation. The types of feedstocks and/or substrates used would also be more attractive to study in the process of anaerobic digestion. This is due to the fact that the types of substrate used and pre-treatment methods applied in anaerobic digestion would significantly affect both the performance of anaerobic digestion process and the end-products produced $[3,4]$.

Starch wastes are a potential feedstock that could be used as a substrate for anaerobic digestion process. This is because they are available abundantly, and contain organic polymers high in carbohydrate [5]. Thus, anaerobic digestion of starch wastes could sustain the production of renewable energy without any competition with the global food stocks. Although starch wastes are biodegradable and easy to hydrolyze, the process of anaerobic digestion is somewhat instable. This is due to the fact that the starch wastes are easily digested, and thereby would potentially increase the formation of intermediate products (i.e. organic acids and alcohols) during the acidogenesis [6].

Organic acids such as volatile fatty acids (VFA) and lactic acid buildup in the anaerobic digester would increase proton $\left(\mathrm{H}^{+}\right)$concentration, and thereby could lower $\mathrm{pH}$ in the culture. Acidic condition would toxify and inhibit the process of anaerobic digestion, and thereby lead to the digester upset $[1,7]$. An imbalance between acid formation and acid utilization occurred since acidification phase that forms VFA could occur at low $\mathrm{pH}$ while methanogens that utilize VFA would be inhibited at low $\mathrm{pH}$. Thus, this condition could lead to acid accumulation in the anaerobic digester $[8,9]$. Study conducted by Yang et al. [9] revealed that a prolonged period of VFA accumulation and low $\mathrm{pH}$ in the digesters would decrease population of methanogens. The authors found that acidic condition caused by the accumulation of VFA would significantly inhibit methanogenesis and the growth of methanogens.

The deficiency of trace elements of starch wastes would also limit the formation of methane gas. This is due to the fact that trace elements play significant role in anaerobic processes $[10,11]$. Some studies showed that the life and growth of microbes during the process of anaerobic fermentation would be highly dependent on the availability and/or sufficient sup- 
ply of nutrients including trace elements, such as nickel, cobalt, and molybdenum [12-14]. Therefore, it is crucial to find the solution to deal with the problems in regards to the deficiency of trace elements in starch waste, and an instable process of anaerobic digestion of starch wastes as a single substrate.

In order to overcome the problem of acid accumulation during the digestion of bio-degradable materials such as starch wastes, the technology of anaerobic co-digestion would be feasible to be applied by combining various types and/or different characteristics of substrates used [15]. Anaerobic co-digestion would generate some benefits as it could lower the operational cost of waste management, enhance digestion efficiency, and also could increase the buffer capacity to stabilize the process of anaerobic digestion $[16,17]$. Some studies had revealed that anaerobic digestion could prevent VFA build-up in the digester, and would provide balance nutrients required for completing the process of anaerobic digestion to form methane as the end-product.

The substrate used in this study was starch waste, which was considered as biodegradable substrate with carbon-rich material [18]. Thus, it would be feasible to combine this substrate with another substrate which contains high concentration of ammonium nitrogen. This would be highly significant as the combination of the substrate with high content of carbon with the substrate with high concentration of ammonium nitrogen would enhance the ratio of carbon to nitrogen in the digester [17, 19]. By conducting co-digestion of these two substrates, the synergetic effect among organic substrates and the performance of anaerobic digestion process would be improved [20,21]. Further, the balance of nutrients needed for the process of anaerobic digestion would also be enhanced [22].

In order to deal with the problems of the imbalance in nutrients during the process of anaerobic digestion of starch wastes, the use of landfill leachate as a co-substrate would be potential [23]. However, when landfill leachate is used as the single substrate for the process of anaerobic digestion, the performance of methanogens to form methane would be restricted by high concentration of ammonia [24]. Thus, by conducting anaerobic co-digestion of starch waste and landfill leachate, the process of digestion would be improved through balancing nutrients and carbon to nitrogen ratio.

Even if the process of anaerobic co-digestion could potentially enhance the production of methane due to the availability of sufficient and balanced nutrients, the risk of acid build-up would still be the major problem once the process is operated in the conventional single stage anaerobic digestion [8, 25]. This potentially occurs as the rate of organic acid or VFA production is higher than the rate of methane formation [26]. To deal with this problem, two-stage anaerobic digestion would be feasible to prevent acid accumulation in the single or conventional anaerobic digesters. 
Two-stage anaerobic digestion would effectively prevent VFA and/ or organic acids accumulation in the digester as in this system the stage of acidification is conducted in the separated reactor of the methanogenesis reactor [27]. Thus, the rapid production of organic acids during the acidogenesis phase would not disturb the methanogenic activities [28]. Further, in the two-stage anaerobic digestion, the conversion of intermediates obtained from the acidification process into methane gas would easily be controlled. This process would help methanogens to utilize VFA effectively in order to form methane as the end-product and to avoid acid accumulated in the reactor, and thereby would significantly enhance methane productivity and yield [29].

In this present study, anaerobic digestion of starch waste was evaluated, and untreated raw landfill leachate was used as co-substrate. The objective of the study was to evaluate the performance of anaerobic co-digestion of starch waste and landfill leachate in single and two-stage processes. The current study also aimed to study the impact of the use of biofilm on methane yield and the effectiveness of starch waste treatment process, as well as to describe the effect of biofilm usage on the prevention of biomass washout during the conversion process of starch waste into methane.

\section{Materials and methods}

\subsection{Substrate and leachate collection}

The raw leachate used as co-substrate for this study was collected from the landfill area located in the Javanese Village, Banda Aceh, Indonesia. Starch waste used for this experiment was collected from the traditional markets located in Peunayong, Banda Aceh, Indonesia. After collecting, starch wastes are sorted and screened to remove any contaminants (i.e plastics, metals,

Table 1. Characteristics of leachate used

\begin{tabular}{|l|c|}
\hline Parameters & Value \\
\hline $\mathrm{pH}$ & $8.08 \pm 0.012$ \\
\hline $\mathrm{COD}(\mathrm{mg} / \mathrm{L})$ & $5837.04 \pm 0.001$ \\
\hline $\mathrm{TKN}(\mathrm{mg} / \mathrm{L})$ & $818.48 \pm 0.010$ \\
\hline $\mathrm{EC}(\mathrm{mS})$ & $16 \pm 0.013$ \\
\hline $\mathrm{TDS}(\mathrm{mg} / \mathrm{L})$ & $8.0 \pm 0.11$ \\
\hline $\mathrm{ORP}(\mathrm{mV})$ & $-111 \pm 0.105$ \\
\hline $\mathrm{BOD}(\mathrm{mg} / \mathrm{L})$ & $30 \pm 1.146$ \\
\hline $\mathrm{NH}_{4}-\mathrm{N}(\mathrm{mg} / \mathrm{L})$ & $9 \pm 1.1$ \\
\hline
\end{tabular}


woods, and stone/sands) that could inhibit the digestion process. The major components of the starch waste used were potatoes, cassava and corn starch. The collected starch waste was crushed, blended and homogenated. The blended starch waste was stored in the fridge at $\pm 4{ }^{\circ} \mathrm{C}$ prior to use. The characteristics of raw leachate landfill used as co-substrate are shown in Table 1.

\subsection{Experimental procedures}

Anaerobic co-digestion of starch waste and leachate was carried out in single and two-stage operations. A 10\% inoculum used to speed up the inoculation process was taken from an anaerobic digester of cow manure. The process of anaerobic digestion was operated under the mesophilic condition at $35 \pm 1^{\circ} \mathrm{C}$. To evaluate two-stage anaerobic digestion process, two sub-sequential reactors are utilized. In order to operate acidogenesis and methanogenesis process, each reactor used has a working volume of $3000 \mathrm{~mL}$. Prior to the start of anaerobic digestion process, each reactor is purged with $100 \% \mathrm{~N}_{2}$ gas for $5-10$ minutes in order to remove oxygen contamination. Hydraulic retention time (HRT) applied for acidogenesis process was 5 days while methanogenesis was 25 days. The flow rates applied to the acidogenesis and methanogenesis reactors were 600, and $120 \mathrm{~mL} /$ day, respectively. The organic loading rate (OLR) used in the process of acidogenesis and methanogenesis were 2.91, and 0.58 gram volatile solid per liter per day (g.VS/L.day).

In order to enhance the performance of anaerobic digesters for optimizing methane productivity, biomass recycling system was applied by using biofilm carrier, which was installed inside in the reactor. In two-stage anaerobic digestion, effluent generated from acidogenesis process will subsequently be used as a substrate for methanogenesis process. This process is applied to optimize the production of methange. Gas generated from methanogenesis reactor will be purified by $4 \mathrm{~mol} / \mathrm{L}$ of sodium hydroxide solution.

\subsection{Analytical methods}

The parameters of influent and effluent obtained from anaerobic acidogenesis and methanogenesis reactors were analyzed in triplicates for $\mathrm{pH}$, oxidation reduction potential (ORP), Total solids (TS), Volatile solids (VS), unseeded biochemical oxygen demand (BOD), total kjedahl nitrogen (TKN), ammonium nitrogen $\left(\mathrm{NH}_{4}-\mathrm{N}\right)$, total dissolved solids (TDS), Electrical conductivity (EC). Measurement of all parameters was carried out according to the Standard Methods [30]. Volatile solids reduction (\%VS reduction) was analysed in order to evaluate the biodegradation efficiency during the process of anaerobic digestion, which was based on the formula mentioned in the previous studies $[31,32]$. Methane production rates were measured as the volume of methane 
generated per day, and the methane yield was measured according to the total methane produced per gram starch or volatile solids added $[27,31]$.

\section{Results and discussion}

\subsection{Anaerobic co-digestion of leachate and starch wast in single-phase process}

In order to evaluate the biodegradability of anaerobic co-digestion of starch waste and leachate in conventional/single stage process, continuous operation under the mesophilic condition was set up with the HRT of 25 days. Table 2 showed the characteristics of influent prior to the process of anaerobic digestion. This experiment showed that anaerobic co-digestion of starch waste and leachate has significant amount of organic materials that could potentially be used as a substrate for methane production in which the percentage of volatile solid represented as organic content was about $98.33 \%$.

As shown in Table 2, the culture of anaerobic co-digestion of starch waste and leachate was somewhat alkaline in which $\mathrm{pH}$ influent obtained was about 7.93. This may indicate that the use of leachate as co-substrate would potentially contribute to the increase of ammonium nitrogen concentration required for balancing high carbon content in starch waste. This is in accordance with the study by Khalid et al. [34], which mentioned that nitrogen in the form of ammonium would contribute to stabilize $\mathrm{pH}$ in anaerobic culture. Some studies revealed that nitrogen is a critical nutrient required for the synthesis of protein and the essence of microbial growth in the process of anaerobic digestion $[34,35]$. Nitrogeneous compounds that contain protein would be converted into ammonium via anaerobic digestion. During the process of

Table 2. Characteristics of influent from anaerobic co-digestion of leachate and starch waste in single stage process

\begin{tabular}{|l|c|}
\hline Parameters & Influent \\
\hline pH & $7.93 \pm 0.015$ \\
\hline TS $(\%)$ & $1.5 \pm 0.05$ \\
\hline VS $(\%)$ & $98.33 \pm 0.22$ \\
\hline TDS $(\mathrm{mg} / \mathrm{L})$ & $2080 \pm 0.15$ \\
\hline EC $(\mathrm{mS})$ & $4.18 \pm 0.02$ \\
\hline BOD $(\mathrm{mg} / \mathrm{L})$ & $29 \pm 1.50$ \\
\hline $\mathrm{NH}_{4}-\mathrm{N}(\mathrm{mg} / \mathrm{L})$ & $8.85 \pm 0.55$ \\
\hline $\mathrm{ORP}(\mathrm{mV})$ & $-112 \pm 0.05$ \\
\hline
\end{tabular}




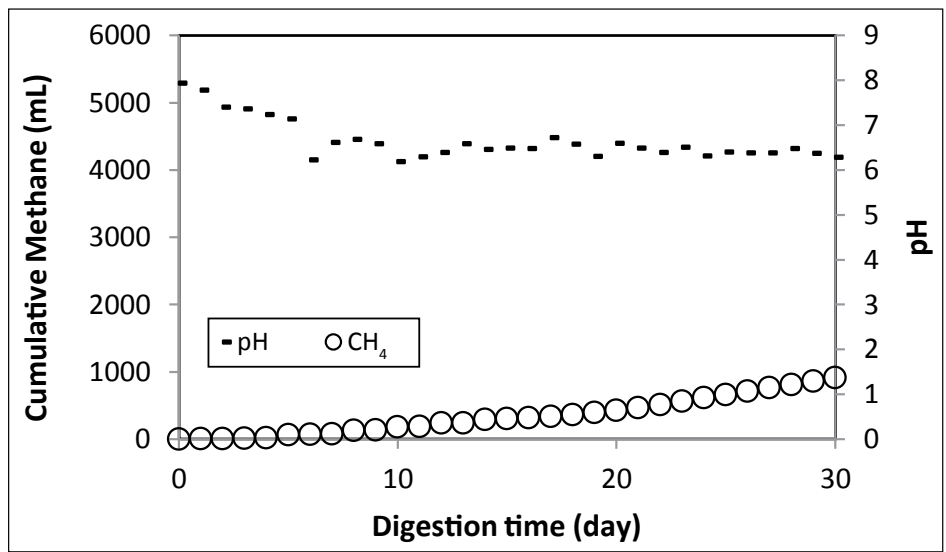

Fig. 1. Cumulative methane production of anaerobic co-digestion of leachate and starch waste

anaerobic digestion, microorganisms would utilize ammonium to form new cell mass $[34,36]$.

Results showed that anaerobic co-digestion of starch waste and leachate carried out in a single-stage operation did not peform satisfactorily in terms of methane production. As depicted in Fig. 1, the total methane production obtained in the process of anaerobic co-digestion of starch waste and raw landfill leachate was less than 1 liter $(910 \mathrm{~mL})$ within 30 days of digestion process. This could be attributed to the drop of $\mathrm{pH}$ during anaerobic digestion process in which $\mathrm{pH}$ culture dropped from 7.93 to 6.22 within 6 days of incubation period. The results are in accordance with the study by Liao et al. [24], which revealed that anaerobic co-digestion of leachate and food waste in a single stage process had a problem of accumulated acid in the digester. The authors found that a drop of $\mathrm{pH}$ was in the range between 4.98 and 5.42. This indicated that acid build-up during the process of anaerobic digestion of foodwaste containing starch would still occur even if the anaerobic digestion was added a co-substrate of leachate which had a rich of nitrogen content.

In this experiment, a drop of $\mathrm{pH}$ started at day 6, and continuously occurred to the end of the anaerobic digestion process tested (day 30). This condition caused acidity in the anaerobic culture, and thereby lowered the production of methane as the end-product $[37,38]$. This occurred as methanogens were quite sensitive in the low $\mathrm{pH}$, and thereby the conversion of intermediates into methane could be inhibited [38]. The results of the experiments also showed that $\mathrm{pH}$ in the digester did not recover during the process of anaerobic digestion even if new fresh substrates were added continuously and the effluents were taken from the reactors simultaneously for 30 days of incubation. This is quite similar to the study conducted by Wang et al. [39], who found that the activitiy of methanogens could not be reconverted once 


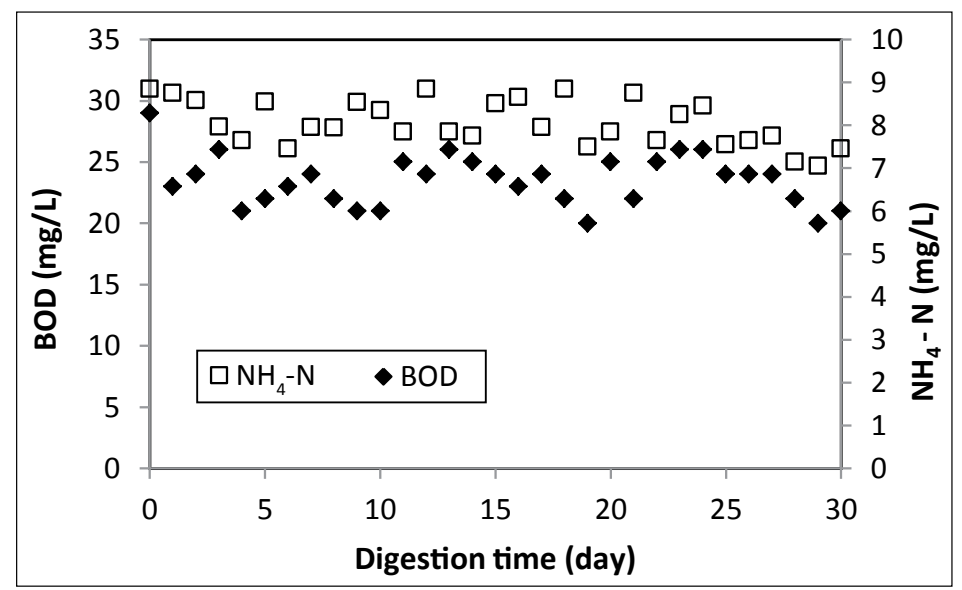

Fig. 2. Variation of concentration of BOD and NH4-N during anaerobic co-digestion of leachate and starch waste

they had been inhibited and exposed to the acidic condition. They reported that VFA accumulated in the digesters, especially propionic acids $(900 \mathrm{mg} / \mathrm{L})$ would significantly inhibit and suppress the activity of methanogens.

Results of the experiments also revealed that during the process of anaerobic co-digestion of starch waste, the concentration of BOD did not decrease significantly in which the concentration was in the range between 30 and $20 \mathrm{mg} / \mathrm{L}$ (Fig. 2). Further, the concentration of ammonia nitrogen fluctuated between 8.85 and $7.45 \mathrm{mg} / \mathrm{L}$. This may indicate that the low $\mathrm{pH}$ in the anaerobic culture could inhibit the degradation of organic materials, thereby could affect the methanogens to produce methane from the oxidation of intermediate products (i.e.VFA). This is in agreement with the study conducted

Table 3. Characteristics of effluent from anaerobic co-digestion of leachate and starch waste in single stage process

\begin{tabular}{|l|c|}
\hline Parameters & Effluent \\
\hline $\mathrm{pH}$ & $6.27 \pm 0.03$ \\
\hline $\mathrm{TS}(\%)$ & $2.47 \pm 0.02$ \\
\hline VS $(\%)$ & $89.88 \pm 0.022$ \\
\hline TDS $(\mathrm{mg} / \mathrm{L})$ & $1940 \pm 0.011$ \\
\hline $\mathrm{EC}(\mathrm{mS})$ & $3.7 \pm 0.015$ \\
\hline $\mathrm{BOD}(\mathrm{mg} / \mathrm{L})$ & $21 \pm 2.105$ \\
\hline $\mathrm{NH}_{4}-\mathrm{N}(\mathrm{mg} / \mathrm{L})$ & $7.45 \pm 1.002$ \\
\hline $\mathrm{ORP}(\mathrm{mV})$ & $-236 \pm 0.001$ \\
\hline
\end{tabular}


by Van Kessel and Russel [38], which revealed that the production of methane would stop when $\mathrm{pH}$ of the culture was lower than 6.0. Further, they reported that the production of methane would recover once $\mathrm{pH}$ of the culture was increased to above 6.0.

\subsection{Two-stage anaerobic co-digestion of leachate and starch waste}

Results from the previous tests revealed that anaerobic co-digestion of starch waste and leachate operated in a conventional and/or single stage did not perform well and produced less methane due to low $\mathrm{pH}$ caused by acid accumulation. In order to avoid acid accumulation and low $\mathrm{pH}$ during the process of anaerobic digestion, the process of co-digestion of starch waste and raw landfill leachate was carried out in the two-stage system. Results of the experiment showed that anaerobic co-digestion of starch waste and leachate operated in the two-stage system could increase methane production with about three times higher in total methane production $(3.3 \mathrm{~L})$ in comparison to the single-stage process $(0.9 \mathrm{~L})$. This occurred as $\mathrm{pH}$ in the process of twostage anaerobic digestion was quite stable in which within 30 days of the operation $\mathrm{pH}$ culture was between 7.5 and 7.30 (Fig. 3, Tables 4, 5).

In terms of organic material removal, there was a tendency that BOD in the culture decreased from 28 to $17 \mathrm{mg} / \mathrm{L}$ (Fig. 4). This result is in agreement with the study by Satyawali and Balakrishnan [40] revealing that during the process of anaerobic digestion, the reduction of BOD indicated that the process of biomethanation occurred. Angelidaki et al. [41], mentioned

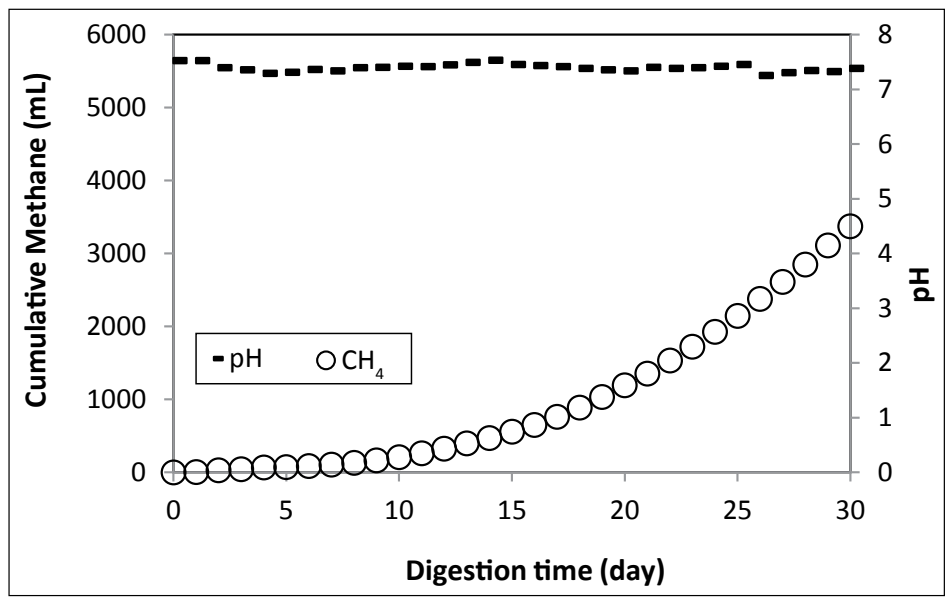

Fig. 3. Cumulative methane production of two-stage anaerobic co-digestion of leachate and starch waste 
Table 4. Characteristics of influent from anaerobic co-digestion of leachate and starch waste in two-stage process

\begin{tabular}{|l|c|}
\hline Parameter & Influent \\
\hline $\mathrm{pH}$ & $7.52 \pm 0.01$ \\
\hline $\mathrm{TS}(\%)$ & $1.52 \pm 0.015$ \\
\hline VS $(\%)$ & $96.67 \pm 0.03$ \\
\hline TDS $(\mathrm{mg} / \mathrm{L})$ & $2820 \pm 0.012$ \\
\hline $\mathrm{EC}(\mathrm{mS})$ & $8.19 \pm 0.01$ \\
\hline $\mathrm{BOD}(\mathrm{mg} / \mathrm{L})$ & $28 \pm 0.011$ \\
\hline $\mathrm{NH}_{4}-\mathrm{N}(\mathrm{mg} / \mathrm{L})$ & $7.95 \pm 0.05$ \\
\hline $\mathrm{ORP}(\mathrm{mV})$ & $-102 \pm 0.001$ \\
\hline
\end{tabular}

Table 5. Characteristics of effluent from anaerobic co-digestion of leachate and starch waste in two-stage process

\begin{tabular}{|l|c|}
\hline Parameter & Effluent \\
\hline $\mathrm{pH}$ & $7.38 \pm 0.01$ \\
\hline $\mathrm{TS}(\%)$ & $2.5 \pm 0.15$ \\
\hline VS $(\%)$ & $65.6 \pm 0.13$ \\
\hline TDS $(\mathrm{mg} / \mathrm{L})$ & $4360 \pm 0.05$ \\
\hline $\mathrm{EC}(\mathrm{mS})$ & $8.2 \pm 0.101$ \\
\hline $\mathrm{BOD}(\mathrm{mg} / \mathrm{L})$ & $17 \pm 1.135$ \\
\hline $\mathrm{NH}_{4}-\mathrm{N}(\mathrm{mg} / \mathrm{L})$ & $5.05 \pm 0.45$ \\
\hline $\mathrm{ORP}(\mathrm{mV})$ & $-125 \pm 0.011$ \\
\hline
\end{tabular}

that biomethanation would occur when the organic wastes/materials were decomposed and converted into biogas in which methane was formed as the end-product of methanogens' activities.

As depicted in Fig. 4, experimental results also revealed that ammonium nitrogen tended to decline within 30 days of the digestion process in which the concentration slightly dropped from 8 to $5 \mathrm{mg} / \mathrm{L}$. Study conducted by Serna-Maza et al. [42] found that total ammonical nitrogen (TAN) in the culture could be significantly reduced when anaerobic digestion of food waste was operated in the semi-continuous system using a-side stripping process. They added that TAN as well as organic nitrogen would be significantly reduced when the process of anaerobic digestion was operated at high temperatures $\left(70\right.$ and $\left.85^{\circ} \mathrm{C}\right)$ and alkaline condition ( $\left.\mathrm{pH} 10\right)$. Maintaining the process 


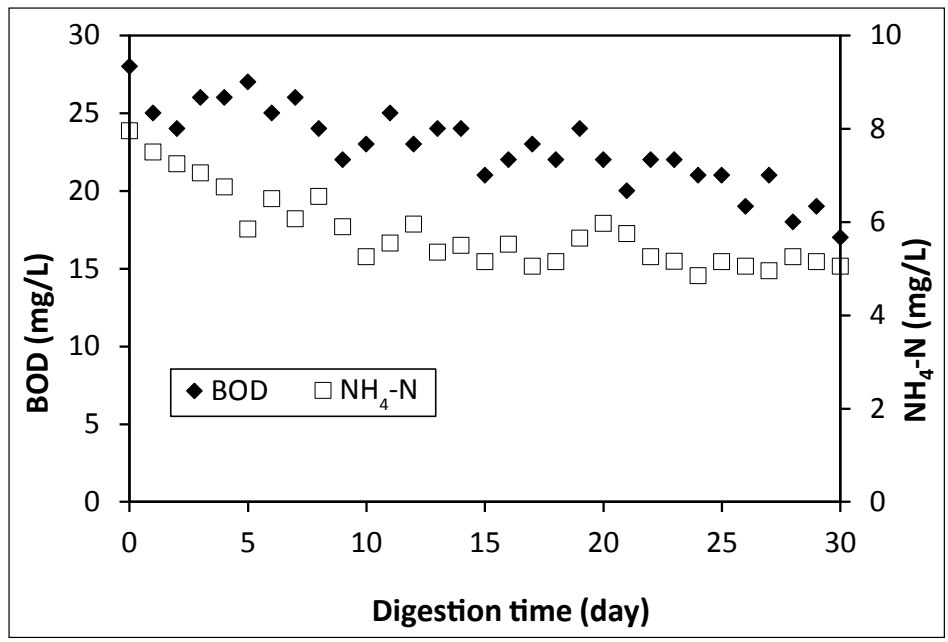

Fig. 4. Variation of concentration of BOD and $\mathrm{NH}_{4}-\mathrm{N}$ during two-stage anaerobic co-digestion of leachate and starch waste

of anaerobic digestion at $\mathrm{pH}$ of 10 would increase the percentage of TAN reduction due to alkaline hydrolysis. In this current study, the concentration of $\mathrm{NH}_{4}-\mathrm{N}$ was somewhat too low $(5-8 \mathrm{mg} / \mathrm{L})$, which was similar to the study by Zhang et al. [23], reporting that low concentration of ammonia-N would indicate that most of nitrogen in anaerobic culture was in the form of organic nitrogen like protein.

\subsection{Two-Stage anaerobic co-digestion of leachate and starch waste using biofilm}

As anaerobic digestion was operated in a continuous mode, there was a tendency that the rate of biomass washout would be higher than the rate of biomass reproduction. If this occurred the production of methane would decrease once the process of anaerobic digestion was operated in the long period. Basri et al. [43] mentioned that biomass washout had been one of the main problems found in the process of anaerobic digestion operated in the continuous system. Thus, in order to prevent biomass washout and optimize methane production, anaerobic co-digestion of starch waste and leachate was conducted by attaching biofilm in the digesters.

Results of the experiments showed that anaerobic co-digestion operated in two-stage process using biofilm could significantly increase methane production. The total production of methane from anaerobic co-digestion using biofilm was about $67 \%$ higher than the co-digestion that was not using biofilm (Figs 3,5). In terms of waste management process, attaching biofilm 
Table 6. Characteristics of influent from anaerobic co-digestion of leachate and starch waste in two-stage process using biofilm

\begin{tabular}{|l|c|}
\hline Parameter & Influent \\
\hline $\mathrm{pH}$ & $7.49 \pm 0.01$ \\
\hline $\mathrm{TS}(\%)$ & $1.55 \pm 0.015$ \\
\hline $\mathrm{VS}(\%)$ & $96.77 \pm 0.011$ \\
\hline $\mathrm{TDS}(\mathrm{mg} / \mathrm{L})$ & $2720 \pm 0.101$ \\
\hline $\mathrm{EC}(\mathrm{mS})$ & $3.61 \pm 0.05$ \\
\hline $\mathrm{BOD}(\mathrm{mg} / \mathrm{L})$ & $26 \pm 1.125$ \\
\hline $\mathrm{NH}_{4}-\mathrm{N}(\mathrm{mg} / \mathrm{L})$ & $5.8 \pm 1.20$ \\
\hline $\mathrm{ORP}(\mathrm{mV})$ & $-97.8 \pm 0.22$ \\
\hline
\end{tabular}

in the digesters could help reduce the organic materials and/or organic pollutant presented in the waste stream. In this current study, the organic materials represented in BOD was reduced significantly from 26 to $9 \mathrm{mg} / \mathrm{L}$, and also ammonium nitrogen decreased from about 6 to $4 \mathrm{mg} / \mathrm{L}$ (Fig. 6). This is in agreement with the study by Lai et al. [44] revealing that the use of biofilm effectively reduced the organic materials in the coking wastewater. They mentioned that reactor attached with biofilm for treating wastewater could significantly reduce chemical oxygen demand (COD) and ammonia nitrogen concentration in which the percentage of $\mathrm{COD}$ and $\mathrm{NH}_{3}-\mathrm{N}$ removal obtained were about 96 and 99\%, respectively.

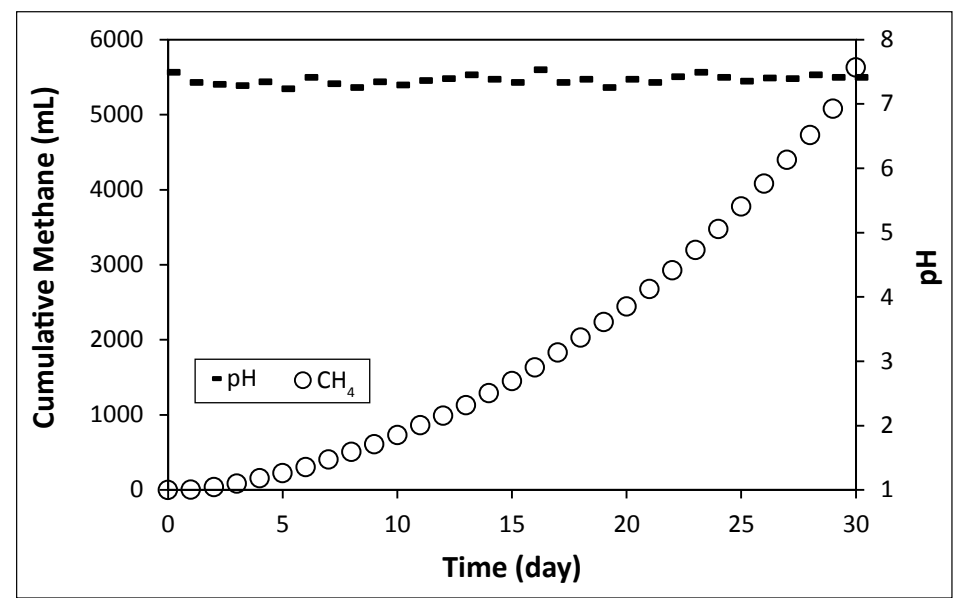

Fig. 5. Cumulative methane production of two-stage anaerobic co-digestion of leachate and starch waste with biofilm 


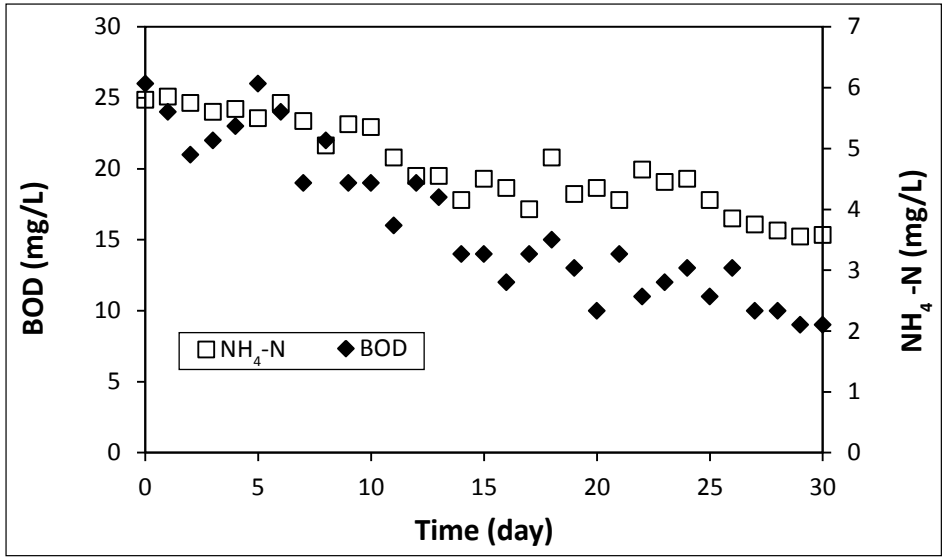

Fig. 6. Variation of concentration of $\mathrm{BOD}$ and $\mathrm{NH}_{4}-\mathrm{N}$ during two-stage anaerobic co-digestion of leachate and starch waste with biofilm

Table 7. Characteristics of effluent from anaerobic co-digestion of leachate and starch waste in two-stage process using biofilm

\begin{tabular}{|l|c|}
\hline Parameter & Effluent \\
\hline $\mathrm{pH}$ & $7.41 \pm 0.02$ \\
\hline TS $(\%)$ & $2.51 \pm 0.04$ \\
\hline $\mathrm{VS}(\%)$ & $37.45 \pm 0.05$ \\
\hline TDS $(\mathrm{mg} / \mathrm{L})$ & $4350 \pm 0.01$ \\
\hline $\mathrm{EC}(\mathrm{mS})$ & $5.11 \pm 0.013$ \\
\hline $\mathrm{BOD}(\mathrm{mg} / \mathrm{L})$ & $9 \pm 1.105$ \\
\hline $\mathrm{NH}_{4}-\mathrm{N}(\mathrm{mg} / \mathrm{L})$ & $3.58 \pm 0.02$ \\
\hline $\mathrm{ORP}(\mathrm{mV})$ & $-109 \pm 0.001$ \\
\hline
\end{tabular}

\subsection{Biodegradation efficiency of anaerobic co-digestion}

In order to evaluate the performance of anaerobic co-digestion process, assessment on the biodegradation efficiency was highly significant [45]. In this current study, some parameters used to evaluate the effectiveness of digestibility and/or coversion on anaerobic co-digestion included methane production and organics removal. Studies mentioned that some parameters used for determining the effectiveness of anaerobic digestion process include volatile solid reduction, total methane production and methane yield [45, 46].

Results of the experiments showed that anaerobic co-digestion of starch waste and leachate operated in the two-stage reactors with biofilm producing 
Table 8. Efficiency of digestion

\begin{tabular}{|l|c|c|c|}
\hline Parameter & Single-phase & $\begin{array}{c}\text { Two-phase } \\
\text { reactor }\end{array}$ & $\begin{array}{c}\text { Two-phase reac- } \\
\text { tor with Biofilm }\end{array}$ \\
\hline Total methane production $(\mathrm{mL})$ & 910 & 3375 & 5630 \\
\hline Methane productivity $\left(\mathrm{mL} \mathrm{CH}_{4} /\right.$ day) & 30.33 & 112.5 & 187.67 \\
\hline Methane yield $\left(\mathrm{mL} \mathrm{CH}_{4} / \mathrm{g} \mathrm{VS}\right)$ & 20.57 & 77.60 & 125.11 \\
\hline Volatile solids reduction $(\%)$ & 8.59 & 32.15 & 61.30 \\
\hline BOD removal $(\%)$ & 27.58 & 39.28 & 65.39 \\
\hline Ammonia removal $(\%)$ & 15.82 & 36.48 & 38.30 \\
\hline
\end{tabular}

more methane per day $\left(188 \mathrm{~mL} \mathrm{CH}_{4} /\right.$ day) in comparison to the reactors operated in single stage system $\left(30 \mathrm{~mL} \mathrm{CH}_{4} /\right.$ day), and two-stage system without using biofilm (112 $\mathrm{mL} \mathrm{CH}_{4} /$ day). As presented in Table 8, methane yield obtained from the two-stage reactor using biofilm was about $125 \mathrm{~mL} \mathrm{CH} 4 / \mathrm{g}$. $\mathrm{VS}_{\text {added }^{\prime}}$ which was about $61 \%$ higher than two-stage reactor without biofilm, and about six times higher than conventional or single-stage operation. The finding of this research is in accordance with the study conducted by Michaud et al. [47] revealing that the methane yield increased with time during biofilm development indicating that the presence of biofilm in the reactor would provide the site for active biomass to stay longer in the anaerobic reactors, and help them convert and decompose organic materials into methane as the main end product. High methane yield obtained due to the fact that biofilm carrier attached into the reactors would enhance the development of biomass indicating that organic materials were highly required for microbial anabolism, and thereby would enhance the reduction as well as conversion of organic matters into methane [47].

The results of the current study also showed that the process of anaerobic co-digestion of starch waste and leachate carried out in the two-stage operation using biofilm was more superior in terms of organic material removal in comparison to the two-stage process without using biofilm and the single stage operation. As shown in Table 8, the co-dgestion operated in the twostage system using biofilm had the highest percentage of volatile solid (VS) reduction $(61 \%)$ and BOD removal $(65 \%)$, in comparison to the two-stage system that only had $32 \%$ of VS reduction and $39 \%$ of BOD removal, and also single-stage or conventional operation that had merely $8 \%$ and $27 \%$ of VS reduction and BOD removal, respectively. The results suggested two-stage anaerobic co-digestion of starch waste and leachate operated in the reactor using biofilm was more effective in degrading organic materials, and also the technology could be applied in order to enhance and optimize the production of methane as a renewable energy. The results of this study are also in agreement with the study by Karadag et al. [48] revealing that the use of 
biofilm in the process of anaerobic digestion could provide high performance stability and hybrid bioreactors, which significantly contributed to increase in methane production, and effectively enhancing organic matter reduction.

\section{Conclusions}

Anaerobic co-digestion of starch waste and landfill leachate operated in the two-stage system could help reduce a drop of $\mathrm{pH}$, and minimize accumulated acid in the bioreactors. In this process $\mathrm{pH}$ was stable in the range between 7.4 and 7.5, while $\mathrm{pH}$ in the single stage system dropped from 7.93 to 6.27 . A stable process in the two-stage anaerobic co-digestion generated almost four times higher methane production $(3400 \mathrm{~mL})$ in comparison to the single stage operation, which only had about $900 \mathrm{~mL}$. Biofilm attached to the reactors operating the two-stage anaerobic co-digestion could effectively increase organics matter removal (65\% of BOD removal), and significantly enhance methane productivity ( $188 \mathrm{~mL} \mathrm{CH}_{4} /$ day). This current finding is highly significant not only for the wastewater treatment plants but also for the industry producing gaseous biofuels.

\section{Acknowledgements}

The authors acknowledge financial support provided by Syiah Kuala University, Banda Aceh, Indonesia through H-index research program coordinated by the Institute for Research and Community Services, UNSYIAH.

\section{Conflict of interest}

The author declares no potential conflicts of interest in regards to the research, authorship, and publication of this paper.

\section{References}

[1] Chen, Y., Cheng, J. J., Creamer, K. S. (2008). Inhibition of anaerobic digestion process: a review. Bioresource technology, 99(10), 4044-4064.

[2] Yenigün, O., Demirel, B. (2013). Ammonia inhibition in anaerobic digestion: a review. Process Biochemistry, 48(5-6), 901-911.

[3] Ariunbaatar, J., Panico, A., Esposito, G., Pirozzi, F., Lens, P. N. (2014). Pretreatment methods to enhance anaerobic digestion of organic solid waste. Applied energy, 123, 143-156.

[4] Koch, K., Helmreich, B., Drewes, J. E. (2015). Co-digestion of food waste in municipal wastewater treatment plants: effect of different mixtures on methane yield and hydrolysis rate constant. Applied Energy, 137, 250-255.

[5] Khongkliang, P., Kongjan, P., Sompong, O. (2015). Hydrogen and methane production from starch processing wastewater by thermophilic two-stage anaerobic digestion. Energy Procedia, 79, 827-832. 
[6] Darwin, Cord-Ruwisch R., Charles W. (2018). Ethanol and lactic acid production from sugar and starch wastes by anaerobic acidification. Engineering in Life Sciences, $18,635-642$.

[7] Xu, Z., Zhao, M., Miao, H., Huang, Z., Gao, S., Ruan, W. (2014). In situ volatile fatty acids influence biogas generation from kitchen wastes by anaerobic digestion. Bioresource Technology, 163, 186-192.

[8] Wang, K., Yin, J., Shen, D., Li, N. (2014). Anaerobic digestion of food waste for volatile fatty acids (VFAs) production with different types of inoculum: effect of pH. Bioresource Technology, 161, 395-401.

[9] Yang, Yu, Meng Xu, Wall, J. D., Zhiqiang Hu. (2012). Nanosilver impact on methanogenesis and biogas production from municipal solid waste. Waste Management, 32, 5, 816-825.

[10] Zhang, L., Lee, Y. W., Jahng, D. (2011). Anaerobic co-digestion of food waste and piggery wastewater: focusing on the role of trace elements. Bioresource technology, 102(8), 5048-5059.

[11] Demirel, B., Scherer, P. (2011). Trace element requirements of agricultural biogas digesters during biological conversion of renewable biomass to methane. Biomass and Bioenergy, 35(3), 992-998.

[12] Bryant, M. P. (1979). Microbial methane production-theoretical aspects. Journal of Animal Science, 48, 193-201.

[13] Scherer, P., Sahm, H. (1981). Effect of trace elements and vitamins on the growth of Methanosarcina barkeri. Acta Biotechnology 1, 57-65.

[14] Schönheit, P., Moll, J., Thauer, R. K. (1979). Nickel, cobalt, and molybdenum requirement for growth of Methanobacterium thermoautotrophicum. Archives of Microbiology, 123(1), 105-107.

[15] Mata-Alvarez, J., Mace, S., Llabres, P. (2000) Anaerobic digestion of organic solid wastes. An overview of research achievements and perspectives. Bioresource Technology, 74(1), 3-16.

[16] Astals, S., Nolla-Ardèvol, V., Mata-Alvarez, J. (2012). Anaerobic co-digestion of pig manure and crude glycerol at mesophilic conditions: Biogas and digestate. Bioresource Technology, 110, 63-70.

[17] Wang, X., Yang, G., Feng, Y., Ren, G., Han, X. (2012). Optimizing feeding composition and carbon-nitrogen ratios for improved methane yield during anaerobic co-digestion of dairy, chicken manure and wheat straw. Bioresource technology, 120, 78-83.

[18] Leung, C. C. J., Cheung, A. S. Y., Zhang, A. Y. Z., Lam, K. F., Lin, C. S. K. (2012). Utilisation of waste bread for fermentative succinic acid production. Biochemical Engineering Journal, 65, 10-15.

[19] Cuetos, M. J., Gomez, X., Otero, M., Moran, A., 2008. Anaerobic digestion of solid slaughterhouse waste (SHW) at laboratory scale: influence of co-digestion withthe organic fraction of municipal solid waste (OFMSW). Biochem. Eng. J. 40, 99-106.

[20] Park, S., Li, Y. (2012). Evaluation of methane production and macronutrient degradation in the anaerobic co-digestion of algae biomass residue and lipid waste. Bioresource Technology, 111, 42-48.

[21] Xie, S., Wickham, R., Nghiem, L. D. (2017). Synergistic effect from anaerobic co-digestion of sewage sludge and organic wastes. International Biodeterioration $\mathcal{E}$ Biodegradation, 116, 191-197. 
[22] Pagés-Díaz, J., Pereda-Reyes, I., Taherzadeh, M. J., Sárvári-Horváth, I., Lundin, M. (2014). Anaerobic co-digestion of solid slaughterhouse wastes with agro-residues: synergistic and antagonistic interactions determined in batch digestion assays. Chemical Engineering Journal, 245, 89-98.

[23] Zhang, W., Zhang, L., Li, A. (2015). Anaerobic co-digestion of food waste with MSW incineration plant fresh leachate: process performance and synergistic effects. Chemical Engineering Journal, 259, 795-805.

[24] Liao, X., Zhu, S., Zhong, D., Zhu, J., Liao, L. (2014). Anaerobic co-digestion of food waste and landfill leachate in single-phase batch reactors. Waste Management, 34(11), 2278-2284.

[25] Zhang, C., Su, H., Baeyens, J., Tan, T. (2014). Reviewing the anaerobic digestion of food waste for biogas production. Renewable and Sustainable Energy Reviews, 38, 383-392.

[26] Maspolim, Y., Zhou, Y., Guo, C., Xiao, K., Ng, W. J. (2015). Comparison of single-stage and two-phase anaerobic sludge digestion systems-Performance and microbial community dynamics. Chemosphere, 140, 54-62.

[27] Parawira, W., Read, J. S., Mattiasson, B., Björnsson, L. (2008). Energy production from agricultural residues: high methane yields in pilot-scale two-stage anaerobic digestion. Biomass and Bioenergy, 32(1), 44-50.

[28] Park, Y., Hong, F., Cheon, J., Hidaka, T., Tsuno, H. (2008). Comparison of thermophilic anaerobic digestion characteristics between single-phase and two-phase systems for kitchen garbage treatment. Journal of Bioscience and Bioengineering, 105(1), 48-54.

[29] Salomoni, C., Caputo, A., Bonoli, M., Francioso, O., Rodriguez-Estrada, M. T., Palenzona, D. (2011). Enhanced methane production in a two-phase anaerobic digestion plant, after $\mathrm{CO}_{2}$ capture and addition to organic wastes. Bioresource Technology, 102(11), 6443-6448.

[30] APHA, (2012) Standard Methods for the Examination of Water and Wastewater, American Public Health Association, Washington, D.C. U.S.A.

[31] Darwin, Cheng, J. J., Liu, Z., Gontuphil, J. (2016a). Anaerobic co-digestion of cocoa husk with digested swine manure: evaluation of biodegradation efficiency in methane productivity. Agricultural Engineering International: The CIGR Journal 18, 147-156.

[32] Darwin, Fazil A., Ilham, M., Sarbaini, Purwanto, S. (2017) Kinetics on anaerobic co-digestion of bagasse and digested cow manure with short hydraulic retention time. Research in Agricultural Engineering, 63(3), 121-127.

[33] Darwin, Cheng J. J., Gontupil J. Liu, Z. M. (2016). Influence of total solid concentration for methane production of cocoa husk co-digested with digested swine manure. International Journal of Environment and Waste Management 17, 1, 71-90.

[34] Khalid, A., Arshad, M., Anjum, M., Mahmood, T., Dawson, L. (2011). The anaerobic digestion of solid organic waste. Waste management, 31(8), 1737-1744.

[35] Kayhanian, M., Rich, D. (1995). Pilot-scale high solids thermophilic anaerobic Digestion of municipal solid waste with an emphasis on nutrientrequirements. Biomass Bioenergy 8, 433-444.

[36] Sawayama, S., Tada, C., Tsukahara, K., Yagishita, T. (2004). Effect of ammonium addition on methanogenic community in a fluidized bed anaerobic digestion. J. Bioscience and Bioengineering 97, 65-70. 
[37] Hook, S. E., Steele, M. A., Northwood, K. S., Wright, A. D. G., McBride, B. W. (2011). Impact of high-concentrate feeding and low ruminal $\mathrm{pH}$ on methanogens and protozoa in the rumen of dairy cows. Microbial Ecology, 62(1), 94-105.

[38] Van Kessel, J. A. S., Russell, J. B. (1996). The effect of pH on ruminal methanogenesis. FEMS Microbiology Ecology, 20(4), 205-210.

[39] Wang, Y., Zhang, Y., Wang, J., Meng, L. (2009). Effects of volatile fatty acid concentrations on methane yield and methanogenic bacteria. Biomass and bioenergy, 33(5), 848-853.

[40] Satyawali, Y., Balakrishnan, M. (2008). Wastewater treatment in molasses-based alcohol distilleries for COD and color removal: a review. Journal of Environmental Management, 86(3), 481-497.

[41] Angelidaki, I., Karakashev, D., Batstone, D. J., Plugge, C. M., Stams, A. J. (2011). Biomethanation and its potential. Methods in Enzymology, 494, 327-351.

[42] Serna-Maza, A., Heaven, S., Banks, C. J. (2014). Ammonia removal in food waste anaerobic digestion using a side-stream stripping process. Bioresource Technolo$g y, 152,307-315$.

[43] Basri, M. F., Yacob, S., Hassan, M. A., Shirai, Y., Wakisaka, M., Zakaria, M. R., Phang, L. Y. (2010). Improved biogas production from palm oil mill effluent by a scaled-down anaerobic treatment process. World Journal of Microbiology and Biotechnology, 26(3), 505-514.

[44] Lai, P., Zhao, H. Z., Zeng, M., Ni, J. R. (2009). Study on treatment of coking wastewater by biofilm reactors combined with zero-valent iron process. Journal of hazardous materials, 162(2-3), 1423-1429.

[45] Wilkie, A. C. (2005) Anaerobic digestion of dairy manure: Design and process consideration. Natural Resource, Agriculture, and Engineering Service, 176, 301-312.

[46] Mata-Alvarez, J., Dosta, J., Romero-Güiza, M. S., Fonoll, X., Peces, M., Astals, S. (2014). A critical review on anaerobic co-digestion achievements between 2010 and 2013. Renewable and Sustainable Energy Reviews, 36, 412-427.

[47] Michaud, S., Bernet, N., Buffière, P., Roustan, M., Moletta, R. (2002). Methane yield as a monitoring parameter for the start-up of anaerobic fixed film reactors. Water Research, 36(5), 1385-1391.

[48] Karadag, D., Köroğlu, O. E., Ozkaya, B., Cakmakci, M. (2015). A review on anaerobic biofilm reactors for the treatment of dairy industry wastewater. Process Biochemistry, 50(2), 262-271. 